\title{
Accumulation and Valorization of the Commonwealth: Some Introductory Notes"
}

\author{
ANDREA FUMAGALLI \\ afuma@unipv.it \\ University of Pavia
}

\begin{abstract}
This paper suggests an analysis of the accumulation and valorisation processes at the heart of the capitalist system and highlights the transition towards a new kind of capitalism - biocognitive capitalism. referring to the Commonwealth as an expression of social cooperation it is suggested that its appropriation is the core of bio-cognitive capitalism.

Additionally, not only how new technologies have deeply affected the mechanisms of capitalist accumulation is described, but also how financialisation has modified the mechanisms of valorisation and its hierarchical structure. To be free, the Commonwealth needs to be endowed with financial autonomy. With the possibility to issue its own currency, the Commonwealth can be free to organise itself and to escape from a logic of exchange value production and from budget constraints imposed by austerity policies.
\end{abstract}

\section{The language as an expression of the commonwealth: preliminary definitions}

After the crisis of the Fordist paradigm, in the last three decades, the accumulation and the valorization processes of the capitalist system went through a deep transformation in. More and more new production factors have become relevant in determining the transition to a new kind of capitalism, which we can define biocognitive capitalism (Fumagalli, 2007; 2011). The advent of bio-cognitive capitalism focuses on learning and relational networks as the basis of the process of accumulation and exploitation. These are, by definition, social phenomena that impliy the development of forms of social cooperation. The organization of cognitive labor is horizontal, as a team, not vertical. If in Taylorism, workplaces were punctuated by messages like "Silence, here we work", in the bio-cognitive capitalism is the language, the communication, which creates value. As Paolo Virno (2005)6:

Let us remember the two famous Aristotelian definition of Homo sapiens: "animal who speaks" and political animal "Animal who speaks": the verbal discourse, an integral part of our biological make-up, qualifies all sorts of feelings and perceptions. For political animal, we intend the trans-character (or, if you prefer, the public) of the human mind, its ability to interact, cooperate, and can adapt to the unexpected. Well, it seems to me that the two ancient

\footnotetext{
- We would like to thank the psychedelic support by the music of Grateful Dead, Jimi Hendrix and The Phish. We thank also the Working Paper Nurery Project (http://www.puntoorg.net/en/home-eng) for the mentoring support received throughout the life of this paper.

${ }^{6}$ See also P. Virno (2002) Grammatica della moltitudine, Roma: Derive Approdi.
} 
definitions summarize well what is meant by life-put-to-work. Actual professional qualities (so to speak) requested to the post-Fordist worker, i.e. all "flexible man", consist of the faculty to signify / communicate and to (inter)act.

The language implies sociability, at the same time creativity and performativity (Austin, 1987 Marazzi, 2008), but also the need for coding. This codification represents the new form in which the fixed capital is reincarnated. In fact, if the physical capital is declining, especially in the Western countries, nonetheless is the role of the fixed capital. In biocognitive capitalism, knowledge, as separate from any product in which it was, is or will be, incorporated, (i.e. when it is mere information and codified communications practice), can exercise in itself a productive action, in the form of standardized language: that is software: can, in other words, play the role of fixed capital (Marazzi, 2005), thus becoming a sort of "cognitive machine", replacing stored labor with living labor, simple or complex as it can be (Stewart, The construction of the software as language is based on living labor supply, which, when it becomes the codification of the language ("cognitive machine"), takes on the appearance of dead labor, fixed capital.

Different is instead the function of the word, as art of communication. In fact, it allows us to analyze the relationship between individuals not only as a tool for its own sake, but as a production and social-performative process (2001).

The word is the becoming of the language, while the language is the codification and systematization of this social production; thus it is regulation and normalization of linguistic creativity of the subjects.

We can thus say that the mechanical codification of language practice, as a convention, today is the mechanical element of bio-economic production, the fixed capital necessary to enhance the living labor of the word as a means of communication, relationship, care and affection.

This opens a dialectic between word and language, or between living labor and dead labor incorporated in the same body / human being.

We define commonwealth this dialectical relationship, the result of the practice of language and of subjective and human relationship, the combination between "animal who is able to speak" and "political animal". Its valorization process requires a new property structure, if it wants to become a prerogative of capital.

Commonwealth is therefore the basis of bio-cognitive capitalistic accumulation Commonwealth can take different forms depending on the mode of accumulation, whether they are based on the exploitation of cognitive-training faculties, or on the relational cooperative faculties. As a first approximation, we can call the first cognitive commonwealth, the second, social re-productive commonwealth.

Commonwealth has nothing to do with common goods: it is simply an expression of social cooperation and of the general intellect. It's necessary to have a clear distinction, the expropriation of the commonwealth goes beyond the dichotomy between private property and public property. This dichotomy is associated to the issue of the management and the use of the commons and the connected choice between privatization and state-ownership. Comonwealth can therefore take various forms depending on the mode of accumulation, 
whether they are based on the exploitation of cognitive-training faculties, or on relationalcooperative faculties.

Commonwealth is in constant metamorphosis, as synthesis between human being and machine. Further, depending on the hybridization between human and machine, commonwealth can take different forms, not necessarily all positive and in any case, constantly evolving.

At the same time, commonwealth is also the product of the bio-accumulation cognitive capitalism.

We agree with Antonio Negri (2016) when he writes:

“... It seems to us that commonwealth constitutes an ontological background, produced by human work in the historical process. Soubassement, background ontology of social reality, produced by labor: what does it mean exactly? That the commonwealth is always a "production", is regulated nature or transformed, or simply produced. The commonwealth is therefore a resource only because it is a product - a product of human labor and therefore under capitalism immediately crossed by power relationships".

Commonwealth, then, as input and output at the same time, that iscumulative process that never ends and feeding due to the social and cooperative nature of the human being and of nature, in its unstable relationship, now with the nature (Marx 1875) ${ }^{7}$, now with the machinic.

We've just underlined that there are two relevant forms of commonwealth: the cognitive commonwealth and reproductive commonwealth.

That the cognitive commonwealth constitutes one of the bio-cognitive accumulation pillars seem to be no doubt.

In the age of cognitive labor, the commonwealth subsumes and highlights the quality of cognitive labor (Negri, 2016).

In bio-cognitive capitalism (where the "potential" - but not actual - hegemony of cognitiverelational work is operating) the labor organization becomes "social organization" and it is gradually conditioned by an increasing production efficiency of cognitive and relational labor. It is the living labor to be ontologically (to use Negri's expression) dominant on dead labor.

This does not mean that dead labor disappears. As already pointed out earlier, the dead labor of machines tend to fixate and to integrate with the living labor of the body-mind (Marazzi, 2005; Morini, 2015).

We are in the presence of a continuity/cumulativity and, at the same time, of an asymmetry: continuity and cumulativity, following the pressure carried by the dynamics of learning economies, are able to push more and more beyond the frontier of knowledge, within a life cycle of knowledge, such as: personal knowledge $\rightarrow$ tacit knowledge $\rightarrow$ socialized knowledge $\rightarrow$ codified knowledge $\rightarrow$ obsolete knowledge (Fumagalli, 2007). We have also an

\footnotetext{
7 "Labor is not the source of any wealth. Nature is the source of use values (and that is the effective wealth) as labor, that it is only the expression of a natural force, human labor force" K. Marz, Critics to Gotha Program).
} 
asymmetry as consequence of the cognitive division of labor and the contradiction between the need for enclosure of the same knowledge and its dissemination in infrastructure and network architectures and relationships, which are continually redefined on hierarchical bases and power.

Thus, cognitive commonwealth is the expression of the dynamic conflict (no longer static as in the past, assuming that it ever was) between capital and labor. Cognitive commonwealth, when it becomes productive capital and produces exchange value, is the expression and conflict "between power of 'living labor' and accumulation of 'dead labor"' (Negri, 2016). The cognitive commonwealth is the expression of a language, the language that is gaining performativity. And it is this performativity that defines it as mode of production. In other words, we are in the presence of a cycle of production of the commonwealth

The valorization of cognitive commonwealth covers the whole production cycle, which is today predetermined on scientific bases by new techniques of human governance. From a technological point of view, we assist to the becoming increasingly machinic of linguistic capacity, not only thanks to the development and dissemination of artificial languages, but more and more thanks to algorithms of new generation, able to capture the nature and human subjectivity (Domingos, 2016).

Negri (2016) writes:

The commonwealth - in time of cognitive and cooperative labor, of General Intellect has a biopolitical status and it is structured by the production of subjectivities. It is commonwealth in a "proper sense", scientific.

In this context, however, while it is true that "the capitalist appropriation comes in a figure totally transformed," it is questionable, in our opinion, to argue that:

The appropriation of surplus labor is exercised not through the direct exploitation of labor and its consequent abstraction but rather through a new mechanism of appropriation, characterized by the extraction of the commonwealth as the constitution of the entire social production (Negri, 2016).

It is evident in this passage the reference to the theory of extractivism (Harvey, 2009) and to the parasitic role of capital, able to exploit the individual singularities at the same time as they relate (Vercellone, 2011).

The commonwealth, as a mode of cognitive production, can not only be subject to formal subsumption processes. If it is true that the dialectic "learning and networking" can set in motion processes of self-valorization and labor liberation, however, this mode of production is not fully-autonomous. We agree with Gerard Raunig (2016: 102), when he writes, introducing the concept of "dividuality", as opposed to "individuality":

The bad news is that dividuality is responsible for most of the increase of exploitation and enslavement that exists in today's machinical capitalism. Algorithms, derivatives, big data and social media technologies all contribute to the rampant expansion of the managerial strategies of division and of desire of self-division.

\footnotetext{
${ }^{8}$ The "dividual" is the divided being, that is no longer perceived as a single moral entity, physical, spiritual. The desire for self-division is now, according to Raunig, one of the most powerful forces in the produce of subjugation and exploitation processes (Raunig, 2016: 71-104).
} 
It is interesting to note that just when the mode of production becomes "common", it replaces the "division."

It is an essential and necessary "division", which creates continuity and discontinuity: continuity because it is the pooling of different individuality that can develop the commonwealth; discontinuities, because, at the same time, it stimulates the fragmentation of living labor and the development of hierarchies in favor of dead labor. The new language machines that even innervate the traditionally manufacturing sectors well represent this ambiguity.

And these algorithms of new generation - from digital management of a warehouse characterized by intensive precarity and exploitation to the Chinese Foxconn, to the new capitalist platforms that inspire the sharing economy, the gig economy and collaborative economy - well represent the synthesis between human and machine, able to produce, in a direct and indirect way, the commonwealth.

Thinking now that the division between manual and cognitive activity is so enough clear and sharp, till to focus the analysis of capital -labor ratio only when the separation between human and machine is just as clear and perceptible, does mean to have misunderstood the forms of the current processes of exploitation and valorization?.

The hybridization with the machine occurs through the exploitation of the cognitive and reproductive commonwealth. Knowledge is the bridge between human and machine and between machine and human, the relationship is the human reproduction. A reproduction that today takes broader connotations, that of social reproduction.

Cristina Morini (2015: 112) writes:

Alisa Del Re aims to systematize it in three fields: the domestic labor or elementary labor, the easiest, transferable, measurable, that can be commercialized immediately and replaced by machines; reproductive labor, i.e. the reproduction of the species, the care of children; care, understood as a sphere in which are expressed human relations, relationships, love, sex. These three domains can interact with each other: the reproductive sphere encompasses, for example, the elementary work and includes the whole sphere for the care of dependent people (including elderly and disabled persons).

More specifically:

"It is social reproduction everything we do to give and stay alive, to ensure the life of the community (preparing food and eating, raise children, take care of the elderly) and living (take a bus to go to work, ask for a 'information to the driver, studying, finding a solution to a problem, interact with a colleague, a project or write an email, learn to play the piano in the evening). Moreover: the reproductive activities are placed in a vertical relationship with respect to the other, that is, to allow, in essence, that all the other are carried out. They underpin, they are the basis of the eternal world spinning. Bringing into light human relationships, emotions and feelings and not just labor force, they also produce identity [...]. It is a "reproduction" that no longer has the purpose and meaning, as in the past, to find (revive) forces with the pause, rest, suspension of the effort once they get home, in private, but that is a dramatic exposure of a public continuum (availability, mobile, messaging, internet, contacts) that highlights the fact that our life is constantly productive ". (Morini, 2015: 112).

\footnotetext{
${ }_{9}^{9}$ As it is implicit in the writings by Carlo Formenti (Formenti, 2016).
} 
In other words, the social reproduction becomes a paradigm of the commonwealth (Morini, 2013).

This example shows clearly how the commonwealth is both input and output of the valorization in bio-cognitive capitalism

And, like any mode of production, it needs to define its field of autonomy. Yet, today, the capacity to be autonomous, like it or not, is forced to pass through the mesh of financial sustainability and capitalist valorization.

\section{The finance money as an expression of capital communism}

The commonwealth is now hostage of capital. Apart from a few notable exceptions ${ }^{10}$, it is the capitalist mode of production to be able to valorize the commonwealth ${ }^{11}$. This is an essential starting point for neo-workerist approach. It is not even a novelty, since it has always been the capital to organize production and today it organizes our lives as well. What has changed is the way in which the relation of exploitation continually redefines the relationship between capital and labor.

This is the metamorphosis that today we need to investigate as attempt to overcome the contradictions posed by the dynamics of social conflicts that innervated the twentieth century, especially in the period leading up to the crisis of the Taylorist-Fordist-Keynesian paradigm.

To this end, it is important to emphasize the spread of digital technologies and financialization, two aspects synergical between themselves.

The former have favored the globalization of manufacturing processes and a new configuration of the relationship human-machine, between fixed and variable capital, between dead and living labor.

\footnotetext{
${ }^{10}$ See some marginal experiences of self-organization: for example, places like Macao and occupied Space of Mutual Aid (SMS) in Milan or others in Rome and in Naples. For an analysis of these experiences of "best practices" is an ongoing European research project Horizon2020, PIE-News, with the participation, as Italian node, of the association Bin-Italia (Basic Income Network).

${ }^{11}$ The expression "communism of capital" is about more than appropriate. This expression is taken by Christian Marazzi (Marazzi, 2015). The term "communism of capital" was, in advance, coined by Antonio Negri along the theoterical analys of the workerist approach in the late Sixties, in a conference held in Padua, whose proceedings wre published in a collective work in 1972 (Aa.V.v 1972) In particular, see Antonio Negri, "John M. Keynes and the capitalist theory of the Sate in '29", p. 100: "The communism of capital can absorb in its movement each value and fully represent the social rules of the development". In this text, Negri refers to the "communism of capital" by analyzing the role of the Keynesian welfare policies that will develop after World War II. Marazzi, however, refers to the illusory role of financial markets to individually create wealth for all ("enrichez vous").
} 
Dwelling on this aspect is not to say that today the entire process of accumulation is based on cognitive labor ${ }^{12}$ and intangible capital. The emphasis on the "immaterial" of some theoretical neo-workerists ${ }^{13}$ or of André Gorz (Gorz 2003) does not deny the materiality of exploitation, far from it. They simply state that the classic dichotomies inside the process of Taylorization of large factory are today put in question and require a redefinition in the light of new governance policies of social conflict also induced by the new technological paradigm brought about by ICT.

The second aspect concerns the financialization process and the new monetary paradigm that has emerged in the last twenty years.

If new technologies have deeply affected the mechanisms of capitalist accumulation, financialization has modified the mechanisms of valorization and its hierarchical structure. Everything starts with the end of Bretton Woods and the complete dematerialisation of money. Its value, usually set in 1944 at Bretton Woods in \$ 35 per ounce of gold, has fallen. After "commodity money " and "gold money", now we are in the era of money as "pure sign" (Marx 1859) ${ }^{14}$, passage which, thanks to the financialization process, has effectively reduced the weight of seigniorage rights and also the possibility by central banks to fully control money supply and the credit and financial multiplier.

Money, thus, tends to dematerialize completely. Today money is no longer a commodity or asset. There is no longer a unit of measure of the value of the money, such as the meter for length, kilograms for weight. Regardless of the fact that there are still monopolies and rights of seigniorage, regardless of the ownership structure, as no longer an asset, money cannot even be called common good. With the end of the Bretton Woods agreements the value of money it is no longer determined, by the institution able to issue it. Monetary sovereignty (national or supranational), whose governance is the task of the Central Bank, loses more and more significance.

With the advent of the capitalist production system, money becomes an expression of capital and social relationship of exploitation of labor. With the transition from Fordist capitalism to financialised and bio-cognitive capitalism, the main function of money is changed.

The Fordist paradigm was the expression of a monetary production economy, that is, an economic process that developed along the three typical phases of a capitalist economy: debt

\footnotetext{
${ }^{12}$ I deliberately use the term cognitive work and not immaterial labor (Lazzarato 1997), since the latter has generated huge misunderstanding. I believe that labour is always innervated by materiality, even when it is eminently cognitive labour or labour that is based on language skills, relational and human care.

${ }^{13}$ The neo-workerist approach (not just post-workerist approach) is a socio-political analysis that spans several areas and is not reducible to a homogeneous thought. Inside, not surprisingly, there are very different thinkers in different times, by Carlo Vercellone to Antonio Negri, by Christian Marazzi to Sergio Bologna, by Matteo Pasquinelli toBenedetto Vecchi, by Michael Hardt to Krystian Szadkowski, by Maurizio Lazzarato to Yann Moulier Boutang, by Sandro Mezzadra to Giso Amendola, by Federico Chicci to Gigi Roggero, by Salvatore Comin to Cristina Morini, just to name a few ...

${ }^{14}$ It was Marx the first who spoke of "money as pure sign (fiat money)". See Marx (1859), especially chapter. II: The coin. The sign of the value: https://www.marxists.org/italiano/marx-engels/1859/criticaep/ 2-2.htm
} 
/ financing, production / accumulation, production / distribution. The first phase was carried out by the banking system under the strict control of the money emission under the monopoly power by the Central Bank, the second was based on standardized, rigid material, production, the third worked on the basis of the ideology of mass consumerism and the reallocation of savings played by the financial markets.

The current bio-cognitive capitalism is rather an expression of a financial production economy (Fumagalli and Lucarelli, 2011a). With this expression we intend to detect the central role played by the financialization process in all three phases: the financial markets expand and change their area of influence up to increasingly shaping the financial intangible productive activities, flexible and globalized, up to intervening as a private social insurance instrument in a distorted and selective way, able to replacing a dismantled and privatized welfare and encouraging income and wealth concentration thanks to capital gains distribution. We highlight that this transformation, leading financial markets to be the accumulation engine of capitalist valorization, takes place simultaneously to the largest concentration process that financial markets have ever experienced since the birth of capitalism.

One of the consequences, just connected to the total dematerialization of money, is that central banks, while maintaining formally the issue monopoly of legal money, have increasingly lost the power to control the creation of liquidity. Nowadays, Central Banks have to "run after" the dynamics the financial conventions that have occurred over the last 25 years (from the Internet Economy '90s until the Chinese and Real Estate economy of the first decade of the new century).

In a financial production economy, also, labor organization is completely different and the outcome of the valorization is not measured by profit but, albeit ambiguously and yet to be studied, from changes in financial values. We believe that financial markets are the place where the expropriation of commonwealth (today, the basis of the processes of accumulation) is realized (Baronian and Vercellone, 2015). If in the Fordist economy the basis for the accumulation and labor exploitation was and is the large factory, nowadays it is the cooperation and the social reproduction, as reminded by Cristina Morini (2015).

We witness a process whereby the financial revenue tends to increasingly subsume the corporate income (profit) (Vercellone, 2011) and, partially, the labor income (wages) (Fumagalli and Morini, 2008), showing that manufacturing and service production exploits more and more social cooperation of the lives put to labor. The paradox (apparent) is that while, from one side, labor that is certified as productive is devalued -, particularly in the high-relational and cognitive industries (what was once called intellectual labor) - from the other, the free life time is put to value, generating thus a mechanism of exploitation and appropriation. The activity of opus, otium and leisure becomes free production, pushing down the remuneration of labor, notably when there is a disciplinary and very strong police device (immigrant status) and / or where there are conditions of blackmail, uncertainty, debt, social control and fear (precarity condition).

There is thus a perverse bond between big finance and precarity: from one side, speculative activity is based on the expropriation of contemporary living labor and it is from this "blood" that capital gains draw nourishment, from the other, it is an imperfect measure, often misleading (as the crisis has shown us) of the productivity of cooperation and of "social" reproduction: it is a cooperation which, as long as it remains almost exclusively precarious 
(as in Italy), is unable to better exploit those learning and network economies that are now the basis of capitalist valorization.

Moreover, big finance and precarity are linked by the fact that not always the command of the former over the latter implies a form of ownership: rather, it is a command based on the control and the exclusivity of management. The oligarchic power by ten finance corporations (from Goldman Sachs to Bank of America Merrill Lynch, from Deutsche Bank to BNPParibas, from Credit Suisse to HSCB, from UBS to JPMorgan Chase) is able to influence the dynamics of financial conventions without a direct ownership of financial portfolios, as well as the precarious life, even when not directly subordinated to the command of capital, can be a source of value for the system of big business (for instance the Platform Capitalism, the sector of social media and the network in general) (Srníček, 2016).

This valorization, creating capital gains, generates liquidity, fueling a financial multiplier that tends to replace the Keynesian multiplier based on deficit spending but with a big difference: the financial multiplier generates bias and distortion in the income distribution while the income multiplier of Keynes was designed to encourage a more equitable income distribution. The distribution process that is generated by the process of financialisation (financial production economy) sets in motion an irreversible process of income polarization, with the consequent and obvious effect of discriminating the access to basic social services (health, housing, education, mobility).

Financial production economy tends to be structurally unstable, as it is based on an unsustainable condition: the positive effects (but distorted) of the financial multiplier on the level of aggregate demand must be constantly able to offset the negative effects on the same level of aggregate demand induced by the growth of concentration in the distribution of incomes and the reduction of the median wage. To make this possible, it is necessary that financial indexes are constantly growing and likely to maintain a high distribution of capital gains: in other words it is necessary that the rich elite consumption could compensate the declining aggregate demand of the poorest and majority population (Fumagalli and Lucarelli, 2011b).

The credit function, typical of a MCM' system - Money - Commodity - Money (monetary production economy), where the investment activity in the production requires a monetary anticipation and the indebtedness of economic agents (private companies or the State), always leaves more space to finance money (financial production economy), that more and more, with the growing role of financialization, is characterized by being a MM - MoneyMoney - system. Finance money, not surprisingly, coincides with the total dematerialization of money, being pure sign-money.

It 'important to note that the shift from credit money to finance money involves a change of monetary governance: the first was and is still issued under the control of the monetary authorities (central banks), while the second, however, depends on the dynamics of financial market.

Until the crisis of Fordism, in fact, the establishment of the Central Bank had the task of exercising a direct and precise control over the money supply (M1) issued by the national State mints (fiat money). But over $90 \%$ of the money supply is now provided by private financial investors and banks, in the form of loans or speculative assets, on whose share Central Bank has only a very indirect control. This means that, despite Central Bank may 
unilaterally and independently sets interest rates and imposes reserve requirements for banks, the amount of money in circulation is less controllable by the same Central Bank. In a capitalist system that is based on a financial production economics, the quantity of money is endogenously determined by the level of economic activity and by the dynamics of financial conventions (in Keynesian terms) that govern the international financial markets. Central Bank can only try to increase or decrease the level of money supply in circulation, but nothing more, chasing and following the dynamics of the same financial indexes. This possibility is now further reduced by the new role played by financial markets in the financing of the investment process, through capital gains and the creation of highly liquid securities (defined near money).

Paradoxically, it follows that the discretionary powers of the central banks are more reduced as much as they themselves have become politically independent institutions. As a result, the power of control and supervision of Central Bank on the banking sector and, through changes in interest rates, on the entire economic system is becoming more functional to the dynamics of financial markets and increasingly dependent on oligarchies that dominate

them.

This means that, in bio-cognitive capitalism, money and the determination of its value are no longer under the control of Central Bank. Money as pure sign escapes any public control. Its value is determined from time to time from speculative activity of financial markets.

Its functions as means of payment and unit of account (a measure of value), as well as a store of value and finance, become out of control. If its quantity and the circulation mode are determined by the conventions that dominate more and more concentrated financial markets, money becomes hostage of the expectations that the financial oligarchy (or rather, the dictatorship of the oligarchy) are able to exercise.

This is why we can say that the creation of money is the expression of the communism of capital (Marazzi 2015; Fumagalli, 2016). It is confirmed by the dependence of monetary policy on financial dynamics. The same interest rates are no longer fully controlled by monetary policy.

Thus, money becomes an expression of the financial bio-power (Lucarelli, 2011), as result of the expropriation of the commonwealth, new form of exploitation of labor in the bio-cognitive capitalism.

\section{Autonomy of the municipality and ambiguity of its enhancement}

The bio-cognitive capitalism is able to expropriate the commonwealth because it is able to activate different processes of life subsumption depending on the context.

The devices that define the governance of life subsumption can be reduced to the following (Fumagalli, 2015): existential precarity, debt and imaginaries capable of generating processes of enslavement and subjection. These devices have the function of combating and annihilating the General Intellect potential surplus that is implicit in the production and social cooperation.

Yet, all this is still not enough. The ability of capital, especially the one represented by hightech multinational corporations, to expropriate the commonwealth lies also in the strategy finalized not only to counteract this potential surplus, but to direct it and control it for the 
benefit of their own interests. An example is provided by the growing interest from investment funds and venture capital towards the proposal of a universal and unconditional basic income. We are talking not of an income support for periods of unemployment, however, aimed to enter in the labor market, but a real income entirely unconnected with the labor activity and not subject to any conditions. We refer in particular to the recent declarations by some managers and CEO of the Silicon Valley in California. In prestigious stages of TED Talk and in personal blogs and major US print media, the stances in favor of granting an unconditional basic income to everyone are significantly increasing.

Albert Wenger, partner of Union Square Ventures, an important investment fund based in New York, already in 2014, in a TED ${ }^{15}$ suggested the need for a basic income. In addition, Wenger has recently put on line After World Capital ${ }^{16}$, a book in which develops and articulates the reasons that underlie basic income. The book is "open" to comments and suggestions because Wenger has decided to share with his audience the same writing of the book. Each paragraph of each chapter brings someone's notes and corrections of someone else. Yet, the final message remains the same: the unconditional basic income will be one of the pillars of the future freedom and it will be the solution to the problem of unstoppable automation and robotics in the future labor activity.

Even Marc Andreessen, another member of the elite of the Venture Capitalists in Silicon Valley, and best known as the founder of Netscape, has repeatedly declared to be in favor of the unconditional basic income, also as a possible solution to the growing inequalities. And Sam Altman, president of YCombinator, a fund (and incubator) Ventur Capitalists in Silicon Valley, which has invested in over 1,000 start-ups - including AirBnB, Dropbox and Instacart, decided to become a full title in the debate by funding research on the basic income to see the effects that different forms of income will have on a group of selected people ${ }^{17}$. It deals with the understanding, from a distance of five years from the start of this social experiment, if these people will be better off economically and if they will acquired new skills and so on. Just up to see if it is at least possible to lower the cost of living in the big cities that, today, in the United States is about 30-40.000 \$ per year. According to Altman, even if $90 \%$ of people who will receive an unconditional basic income decide to do nothing, the remaining $10 \%$ would have the opportunity to develop and apply their creativity and compensate with innovative new products the lower productivity of all the others ${ }^{18}$. If these examples are quite explicit in expecting a capture by capital of social cooperation and general intellect, following what happens in the platform capitalism and in the sharing economy (for example, when it is used crowdfunding), nevertheless there are some degree of ambiguity.

\footnotetext{
${ }^{15}$ https://www.youtube.com/watch?v=t8qo7pzH NM

${ }^{16} \mathrm{http}: / /$ worldaftercapital.org/

${ }_{17}$ For further information on the experiment funded by Altman, see http:// freakonomics.com /podcast/mincome/. For a deeper discussion on the basic income hypothesis in Silicon Valley, see. http://www.bin-italia.org/silicon-valley-per-il-reddito-di-base/; http://www.bin-italia.org/reddito-dibase-incondizionato-e-i-venture-capi-talist-della-silicon-valley/

${ }^{18}$ A similar project became operational in Finland since 1 January 2017. It will cover a sample of 2,000 citizens randomly selected among those who do not have jobs, who will be awarded a grant of 560 Euros monthly, without any condition (even no suspension in case they managed to find work). The 560 euro cover all the benefits to which such persons may be eligible
} 
An interesting case, in the middle between subsumption and subversion, is represented by the first attempts to produce alternative cooperation platforms, able to creep into the contradictions of capital itself.

In finance, an interesting case is that of Robin Hood Asset Management Cooperative, a cooperative management of financial assets established in June of 2012, which has the ambition to be a kind of

Bank of counter-investment of the precariat, which is rethinking the means of finance and of financial services. We are bending the financialization of the economy to our advantage (Piironen, 2015: 152).

By using a dynamic mining algorithm of new generation (defined parasite), in order to get hold of the data of the main speculators on Wall Street, Robin Hood is able to carry out speculative activity on the same level of the "enemies ". The results were more than gratifying. In 2013, the value of the portfolio rose by $30.74 \%$, thus resulting the third best hedge fund in the world. In 2014, the return was $40.15 \%$ of the financial investment, although in the last two years there has been a decline in line with the trend of world stock markets, after the burst of real estate bubble in China and the Philippines in summer 2015.

The revenues of this pure speculative activity are then used to fund antagonist projects related to self-production sphere and social self-organization (the commonwealth), in line with the motto of Robin Hood, "stealing from the rich to give to the poor". Although this is a different type of project finance from venture capitalists in Silicon Valley, I do not think we can say that it is an experimentation that is able to guarantee autonomy to the commonwealth managing. The possibility, in fact, to break away completely from the dynamics of the capitalist financial governance is not given. The possibility of developing financial autonomy able to finance the commonwealth depends ultimately on the efficiency instance of speculative machine to create liquidity, just as with the matching funds of private pension provision in terms of the level of the future pensions.

The interest (in term of Olivetti style) of international capital towards social cooperation and growth of General Intellect is easily understood if it is designed to stimulate the same social cooperation, which, to be as more creative as possible and therefore productive, can only stay free from any type of conditioning: must be pure creativity. Far from being potentially subversive, such creativity, if developed within a "certain ideology" (the "Californian ideology": Barbrook and Cameron 1996), is easily subsumed and "naturally" folded to the interests of continuous innovation and experimentation to test new ways of producing exchanges value.

It is therefore clear that in this case one cannot speak of the commonwealth autonomy, even if it seems that the condition to activate such autonomy e superficially created. The wire puppeteer who intervenes here is therefore thinner and takes the shape of monetary-financial incentive: a kind of new high wage policy to increase social productivity. Note that, in this regard, albeit in a more moderate way, the large Californian corporations of communication have already operated in this direction, particularly through the provision of indirect income but only in favor of their employees. It is an indirect and supplementary income that is expressed both as corporate welfare as a direct participation to capital gains generated by the financial markets. 
Albeit spread out over time and not immediately striking, it is still the monetary constraint to dictate the subordination of labor to capital.

The commonwealth will actually become (and not just formally or potentially) independent only if it is able to sever that link.

Only if it is able to experiment with forms of monetary and financial autonomy, the commonwealth can be free to organize itself and to escape from a logic of exchange value production (Braga and Fumagalli, 2015).

It follows that the monetary autonomy is necessary (although not sufficient) for the autonomy of the commonwealth, instrument, among others, to promote a constituent exodus process.

Speaking today of monetary autonomy does not mean rebuilding a monetary sovereignty, overcome in Europe by the monetary, and to which the nostalgic nationalist populism aspires, even among some nostalgic leftist groups.

Monetary sovereignty no longer exists: it is a concept that does not make much sense. Although some national sovereignty formally still holds in the monopoly on issuing money (as in the US, Japan and most of the national states), as we have argued, this does not imply the ability to control the money supply. Even central banks, in fact, are subordinate to the logic of financial conventions that are defined from time to time on the basis of the dynamics of the same financial hierarchies.

Monetary (and financial) autonomy means therefore not be subject to such financial conventions. It means to escape from traditional financial circuits, be they also virtual. To do that, it is necessary to imagine a new monetary instrument. It is not enough for such a currency to be complementary to the existing currencies, it must be alternative to them. Today, technology allows us to create money in digital form: the so-called crypto-currencies. The new aspect is the loss of the monopoly of issue: it is no longer the monetary institutions, which, (very little) democratically, have the power how to decide the monetary and financial policy, thanks to the emission monopoly. It can (should) be a multitude of individuals who, themselves, have the ability to digitally creating money and all those individuals who decide (trusting) to recognize the monetary value of that alternative money.

In this time of mechanic algorithms, it is not surprising that money may not be printed, but rather "extracted" (mining) and that the course of this currency is not validated by supraindividual institutions, but by the formal correctness of an algorithm executed by machines and / or decisions of a financial and techno-elite.

This new situation is a challenge and at the same time a chance to build an alternative financial and monetary system as a prerequisite for the autonomy of the commonwealth, able to overcome the contradictory and unfair nodes of contemporary capitalism. We will discuss this perspective in a future article.

\section{Keywords}

Commonwealth; bio-cognitive capitalism; financialisation. 


\section{Reference list}

Austin J.L. (1987) Come fare cose con le parole, Turin: Marietti.

Baronian, L., Vercellone, C., "Moneta del comune e reddito sociale garantito", In La moneta del comune. La sfida dell'istituzione finanziaria del comune, E. Braga and A. Fumagalli (eds), pp. 21-40, Roma: Derive Approdi - Alfabeta.

Barbrook, R., Cameron, A. (1996) [1995] "The Californian Ideology", Science as Culture, 6 (1): 44-72

Domingos, P. (2015) The Master Algorithm: How the Quest for the Ultimate Learning Machine Will Remake Our World, New York: Basic Books.

Formenti, C. (2016) La variante populista, Rome: Derive Approdi.

Fumagalli, A. (2007) Bioeconomia e capitalismo cognitivo. Verso un nuovo paradigma di accumulazione, Roma: Carocci.

Fumagalli, A. (2011) "Twenty Theses on Contemporary Capitalism (Cognitive Biocapitalism)", Angelaki, 16: 7-17

Fumagalli, A. (2015) "The concept of Subsumption of Labour to Capital. Towards the Life Subsumption in Bio-cognitive Capitalism", In Reconsidering Value and Labor in the Digital Age, E. Fisher, C. Fuchs (eds), pp. 224-245, London: Palgrave, McMillan.

Fumagalli, A. (2016) Grateful Dead economy. La psichedelia finanziaria, Milano: Agenzia X, 2016

Fumagalli, A., Lucarelli S. (2011a) "A Financialized Monetary Economy of Production", International Journal of Political Economy, 40 (1): 48-6.

Fumagalli, A., Lucarelli S. (2011b) “A Macroeconomic Policy in Cognitive Capitalism Paradigm", In Credit, Money And Macroeconomic Policy. A Post-keynesian Approach, C. Gnos, L. F. Rochon (eds), pp. 313-334, London: Elgar Publisher.

Fumagalli, A, Morini C. (2008) "Segmentation du travail cognitif et rente salariale", Multitudes, 32: 75-84.

Gorz, A. (2003), L'immateriale, Turin: Bollati Boringhieri.

Harvey, D. (2009) “The 'New' Imperialism: Accumulation by Dispossession", In Socialist Register, vol. 40. On line at http://socialistregister.com/index.php/srv/article/view/5811\#. WKXNH3-yIUI, accessed, on march 2016

Lazzarato, M. (1997) Lavoro immateriale, Forme di vita e produzione di soggettività, Verona: Ombre Corte.

Lucarelli, S. (2009) "La finanziarizzazione come forma di biopotere", In Crisi dell'economia globale. Mercati finanziari, lotte sociali e nuovi scenari politici, A. Fumagalli, S. Mezzadra (eds), pp. 101-120, Verona: Ombre Corte.

Marazzi, C. (2005) "L'ammortamento del corpo-macchina", In Reinventare il lavoro, J. L. Laville et al. (eds), Roma: Sapere 2000.

Marazzi, C. (2008), Capital and Language. From the New Economy to the War Economy, Semiotext(e), Cambridge, MASS: Mit Press.

Marazzi, C. (2015) Il comunismo del capitale, Verona: Ombre Corte. 
Marx, K. (1859) Per la critica dell'economia politica, 1859, [Firenze: Klinamen, 2011]

Marx, K. (1875) Critica del Programma di Gotha, Note in margine al programma del Partito operaio tedesco. On line at https://www.marxists.org/italiano/marx-engels/1875/gotha/cpg-cp.htm accessed, on march 2016

Morini, C. (2013) "Social Reproduction as a Paradigm of the Common. Reproduction Antagonism, Production Crisis" In Post-Crisis Perspectives. The Common and its Powers, O. G. Augustin, C. Ydesen (eds), pp. 83-98, Frankfurt: Peter Lang.

Morini, C. (2015) "Riproduzione sociale", In La piccola enciclopedia precaria, C. Morini, P. Vignola (eds), pp. 106-122, Milano: Agenzia X.

Negri, A. (1972) “John M. Keynes e la teoria capitalistica dello Stato nel '29", In Operai e Stato, Vv.Aa., pp. 69-101, Milano: Feltrinelli.

Negri, A. (2016) "Il comune come modo di produzione", 5 giugno 2016. On line at http://www.euronomade.info/?p=7331 accessed, on march 2016.

Piironen, P. (2015) “Democratizzare il potere della finanza: una discussione su Robin Hood Asset Management Cooperative con Akseli Virtanen" in La moneta del comune. La sfida dell'istituzione finanziaria del comune, E. Braga, A. Fumagalli (eds), pp. 152-169, Alfabeta2 Roma: Derive Approdi.

Raunig, G. (2016) Dividum: machinic capitalism and molecular devolution, New York: Semiotexte.

Srnicek, N. (2016) Platform Capitalism, London: Polity Press.

Stewart, T.A. (2001), The wealth of knowledge: Intellectual capital and the twenty-first century organization, New York: Currency.

Vv. Aa. (1972) Operai e Stato, Milan: Feltrinelli, (contributors: Sergio Bologna, George P. Rawick, Mauro Gobbini, Antono Negri, Luciano Ferrari Bravo, Ferruccio Gambino).

Vercellone C. (2009) “Crisi della legge del valore e divenire rendita del profitto. Appunti sulla crisi sistemica del capitalismo cognitivo", In Crisi dell'economia globale. Mercati finanziari,lotte sociali e nuovi scenari politici, A. Fumagalli and S. Mezzadra (eds), pp. 71100, Verona: Ombre Corte.

Virno, P. (2002) Grammatica della moltitudine, Rome: Derive Approdi.

Virno, P. (2005), “Un movimento performativo", april 2005. On line at http://republicart.net/disc/precariat/virno01_it.html, accessed, on March 2016. 